\title{
Metabolic and energy status during the dry period is crucial for the resumption of ovarian activity postpartum in dairy cows
}

\author{
N. Castro, ${ }^{*} \dagger^{1}$ C. Kawashima, $\ddagger^{1}$ H. A. van Dorland, ${ }^{*}$ I. Morel, $\S$ A. Miyamoto, $\ddagger$ and R. M. Bruckmaier ${ }^{* 2}$ \\ *Veterinary Physiology, Vetsuisse Faculty, University of Bern, 3001 Bern, Switzerland \\ †Department of Animal Science, Las Palmas de Gran Canaria University, Arucas 35413, Spain \\ $\ddagger$ Graduate School for Animal and Food Hygiene, Obihiro University of Agriculture and Veterinary Medicine, Obihiro 080-8555, Japan \\ §Agroscope Liebefeld-Posieux (ALP), 1725 Posieux, Switzerland
}

\begin{abstract}
It is well known that the degree of negative energy balance in high-producing dairy cows is the major cause of delayed resumption of the ovarian cyclicity that closely relates to fertility. Recent evidence suggests that the energetic situation during early lactation critically affects nutrient partitioning, metabolism, and the reproductive axis, whereas the effect of energy status during the dry period is widely unknown. The aim of the present study was to investigate the effect of energy status throughout the entire dry period until early lactation on the onset of the ovarian cyclicity. Blood samples were taken in 23 cows from dry off at $8 \mathrm{wk}$ before expected parturition to $8 \mathrm{wk}$ postpartum for the analyses of metabolites and hormones, and milk samples were obtained 3 times weekly from d 7 of lactation onward to confirm luteal activity and pregnancy by milk progesterone analysis. Energy balance (EB) was measured weekly during the last 6 wk of the dry period and every other week after parturition. Liver biopsies were obtained at $8 \mathrm{wk}$ before expected calving, within $1 \mathrm{~d}$ after calving, and at 4 wk postpartum to measure the mRNA abundance of various gluconeogenic enzymes and metabolic hormone receptors. Cows showing luteal activity within 3 wk postpartum were defined as ovulatory during the first follicular wave postpartum (OC), whereas cows without luteal activity within 3 wk postpartum were defined as anovulatory (AC). Energy balance and, concomitantly, plasma concentrations of glucose, insulin, insulin-like growth factor-1, 3,5,3'-triiodothyronine, and thyroxine were higher in $\mathrm{OC}$ than in $\mathrm{AC}$ during the dry period. Plasma thyroxine concentrations and body condition score during the postpartum period were higher in OC than in AC. At the mRNA level (19 cows), hepatic
\end{abstract}

Received April 27, 2012.

Accepted June 16, 2012.

${ }^{1}$ These authors contributed equally to this work.

${ }^{2}$ Corresponding author: rupert.bruckmaier@vetsuisse.unibe.ch insulin receptor decreased from dry off to early lactation, and mRNA of pyruvate carboxylase was highest at parturition and decreased in early lactation in $\mathrm{AC}$ only, whereas both parameters remained unchanged in OC. The mRNA abundance of phosphoenolpyruvate carboxykinase-mitochondrial increased from dry off to parturition in both groups, remained high in OC, and decreased again in early lactation in AC. However, none of the investigated gene transcripts differed between $\mathrm{OC}$ and AC cows. Thus, ovarian function postpartum appears to be crucially influenced by the energy status during the dry period, which is reflected by timely changes in hepatic mRNA abundance of only a few key metabolic factors in the liver.

Key words: dairy cow, energy status, first ovulation, liver mRNA abundance

\section{INTRODUCTION}

The first ovulation after parturition is usually observed within 3 wk postpartum (pp) in about $50 \%$ of healthy cows (Lucy et al., 1992; Darwash et al., 1997; Kawashima et al., 2007a,b). It is generally accepted that early resumption of ovarian function is related to high fertility (Staples et al., 1990; Senatore et al., 1996; Darwash et al., 1997). However, in almost 50\% of cows, the dominant follicles are not able to ovulate and become atretic or cystic (Savio et al., 1990; Sakaguchi et al., 2004; Kawashima et al., 2007b). One of the major causes of delayed resumption of ovarian function in high-yielding dairy cows is the level of negative energy balance (NEB), which usually occurs during the postpartum period because the energy required for milk production and maintenance of tissues function is higher than energy uptake (Beam and Butler, 1999; Lucy, 2001) during that period. Butler and Smith (1989) observed that NEB was directly related to the postpartum interval to first ovulation, and that differences in energy balance (EB) were reflected in the milk yield. Staples et al. (1990) showed that cows having delayed resumption of luteal activity had greater NEB 
between the first and second week postpartum compared with cows having resumed luteal activity early.

Elevated concentrations of growth hormone (GH) and concomitantly low concentrations of glucose, insulin, and IGF-1 represent the typical metabolic situation during NEB postpartum (Roche et al., 2000; Gross et al., 2011). These factors are obviously associated with ovarian activity (Butler, 2000; Armstrong et al., 2003; Lucy, 2003). In particular, IGF-1 and insulin are key factors for the ovarian function because they both stimulate estradiol-17 $\beta$ production in granulosa cells (Gutiérrez et al., 1997; Glister et al., 2001) and proliferation of follicular cells (Spicer et al., 1993; Spicer and Stewart, 1996). Levels of circulating IGF-1 during the first follicular wave postpartum are higher in ovulatory cows than in anovulatory cows (Beam and Butler, 1998; Kawashima et al., 2007b).

The expression of GH receptor (GHR)1A and IGF-I mRNA in the liver declines at parturition, representing the so-called uncoupling of the GH-IGF axis, resulting in cows showing higher GH and lower IGF-1 concentrations in plasma after parturition compared with advanced lactational stages (Radcliff et al., 2003). Hence, hepatic GHR concentration is positively correlated with plasma IGF-I and level of nutrition, and therefore with the metabolic status of the animal, in which insulin appears to be a key metabolic signal in recoupling the GH-IGF axis (Butler et al., 2003). Moreover, depending on the level of nutrition postpartum, hepatic adaptations involve changes in the expression and activity of enzymes for hepatic gluconeogenesis such as pyruvate carboxylase (PC) (Hammon et al., 2003) and phosphoenolpyruvate carboxykinase (PEPCK; Greenfield et al., 2000), thus directly linking to the hepatic gluconeogenic capacity.

Most previous studies have investigated the relationship between metabolic status during the early postpartum period and the resumption of the ovarian activity after parturition, whereas detailed information on the effect of the prepartum period is still lacking. de Feu et al. (2009) showed evidence that eliminating the dry period advanced the first ovulation postpartum, but feeding a higher energy diet for 12 wk pp had no effect on the onset of cyclicity. Another study (Cavestany et al., 2009a,b) indicated that feeding a high-supplemented prepartum diet to cows also advanced first ovulation postpartum. These studies suggest that the energy supply during the dry period critically affects nutrient partitioning, metabolism, and the reproductive axis. Therefore, the aim of the present study was to investigate, in detail, the effect of metabolic status together with mRNA abundance of key metabolic factors in the liver throughout the dry period and in early lactation on the resumption of the ovarian cyclicity in dairy cows.

\section{MATERIALS AND METHODS}

\section{Animals, Feeding, and Management}

The experimental procedures followed the Swiss Law on Animal Protection and were approved by the Committee of Animal Experiments of the Canton Fribourg, Switzerland. The present study involved 23 multiparous dairy cows of parities 2 to 6 of the breed types Brown Swiss, Holstein, and Swiss Fleckvieh (Simmental $\times$ Red Holstein). Cows were held at the Swiss Federal Research Station Agroscope Liebefeld-Posieux (ALP, Posieux, Switzerland). The experimental cows had a mean BW of $666 \mathrm{~kg} \pm 10.7 \mathrm{~kg}$ (mean $\pm \mathrm{SEM}$ ), and they had produced $23.3 \mathrm{~kg} \pm 1.3 \mathrm{~kg} / \mathrm{d}$ of milk in their previous lactation (based on a 305-d milk production). The study started with drying off at $8 \mathrm{wk}$ before the expected parturition and lasted until $8 \mathrm{wk}$ pp. During the dry period, cows were fed similar diets composed of hay (DM basis, consisting of $59 \mathrm{~g}$ of $\mathrm{CP}$ per $\mathrm{kg}$ and 4.1 MJ of $\mathrm{NE}_{\mathrm{L}} / \mathrm{kg}$ ) and concentrate. Additionally, straw (DM basis, consisting of $23 \mathrm{~g}$ of $\mathrm{CP}$ per $\mathrm{kg}$ and 1.8 MJ of $\mathrm{NE}_{\mathrm{L}} / \mathrm{kg}$ ) was always accessible. One week before parturition, cows were gradually adapted to the lactation diet, which was fed solely from parturition onward. After parturition, cows received a lactation diet, which was a mixture of grass silage (DM basis, consisting of $194 \mathrm{~g}$ of $\mathrm{CP}$ per $\mathrm{kg}$ and $6.6 \mathrm{MJ}$ of $\mathrm{NE}_{\mathrm{L}} / \mathrm{kg}$ ), maize silage (DM basis, consisting of $76 \mathrm{~g}$ of $\mathrm{CP}$ per $\mathrm{kg}$ and 6.6 MJ of $\mathrm{NE}_{\mathrm{L}} / \mathrm{kg}$ ), and potatoes (DM basis, consisting of $85 \mathrm{~g}$ of $\mathrm{CP}$ per $\mathrm{kg}$ and $7.7 \mathrm{MJ}$ of $\mathrm{NE}_{\mathrm{L}} / \mathrm{kg}$ ) in equal amounts. Additionally, minerals were fed, and an energy-rich concentrate (DM basis, consisting of $120 \mathrm{~g}$ of $\mathrm{CP}$ per $\mathrm{kg}$ and $8.0 \mathrm{MJ}$ of $\mathrm{NE}_{\mathrm{L}} / \mathrm{kg}$ ), and a protein-rich concentrate (DM basis, consisting of $581 \mathrm{~g}$ of $\mathrm{CP}$ per $\mathrm{kg}$ and 8.1 MJ of $\mathrm{NE}_{\mathrm{L}} / \mathrm{kg}$ ) were fed according to each cow's extra requirements for milk production. Hay (DM basis, consisting of $152 \mathrm{~g}$ of $\mathrm{CP}$ per $\mathrm{kg}$ and 6.2 MJ of $\mathrm{NE}_{\mathrm{L}} / \mathrm{kg}$ ) and water were always accessible. During the entire study, cows were housed in a freestall barn with permanent access to an enclosed yard outside. Cows were milked twice daily between 0445 and $0615 \mathrm{~h}$ and between 1600 and $1730 \mathrm{~h}$.

\section{BW, BCS, Milk Yield, Milk Components, and Energy Balance}

Cows were weighed individually weekly during the dry period. Body condition score was assessed at parturition and once a month from 2 mo before parturition to 2 mo after parturition. The BCS was always recorded by the same individual on a 0 to 5 scale with 0.25 intervals $(0=$ thin and $5=$ very fat $)$ according to Ferguson et al. (1994). 
Feed samples were collected weekly before parturition and every 2 wk after parturition and pooled to form 3 to 4 samples per feed component, which were subsequently analyzed for chemical composition during routine analyses at the ALP Research station as described by Graf et al. (2005).

Milk yield was recorded at each milking for each cow individually. Milk samples were taken 4 times per week for the determination of the content of milk fat, protein, and lactose with a method used in routine milk control (CombiFoss 6000, Gerber Instruments AG, Effretikon, Switzerland) at the laboratory of the Holstein Association of Switzerland (Grangeneuve, Switzerland). In addition, milk samples for progesterone $\left(\mathbf{P}_{4}\right)$ determination were collected from the whole milk after the afternoon milking 3 times weekly from d 7 of lactation until a new pregnancy, and samples were stored at $-20^{\circ} \mathrm{C}$ until $\mathrm{P}_{4}$ analyses.

The EB was estimated for each cow, based on the recorded daily feed intake for each cow individually through electronic identification (responders) and controlled by feeding doors registering intake at each access through electronic feed balances (Insentec B.V., Marknesse, the Netherlands). The EB before parturition was estimated as the difference between the energy intake [based on tabular values for $\mathrm{NE}_{\mathrm{L}}$ of feeds (ALP, 2007) and measured DMI per animal] and the energy output $\left[\mathrm{NE}_{\mathrm{L}}\right.$ requirements for maintenance and gestation, determined from tabulated values and recommended equations according to ALP (2007)]. The EB after calving was calculated similarly, but for energy output, energy requirements for milk production were included instead of those for gestation.

\section{Blood Collection and Analysis}

Blood samples were taken from the jugular vein every 2 wk between 0830 and $1000 \mathrm{~h}$ from 8 wk before expected parturition and for $8 \mathrm{wk} \mathrm{pp}$. In the weeks when a liver biopsy was planned, blood samples were taken on the same day but before the biopsy. Blood samples were collected in evacuated tubes containing tri-potassium-EDTA and immediately put on ice. Plasma was obtained via centrifugation for 20 min at 1,500 $\times g$. Plasma for the determination of glucose, NEFA, BHBA, total (T)-cholesterol, aspartate aminotransferase (AST), gamma-glutamyl transferase (GGT), insulin, IGF-I, 3,5,3'-triiodothyronine $\left(\mathbf{T}_{\mathbf{3}}\right)$, and thyroxine $\left(\mathbf{T}_{4}\right)$ was stored at $-20^{\circ} \mathrm{C}$ until analyzed.

Plasma concentrations of metabolites were measured enzymatically by using kits as described by Vicari et al. (2008). Concentrations of glucose and T-cholesterol and activities of AST and GGT were measured with kits from bioMérieux (Marcy l'Etoile, France; kit nos. $61270,61219,63212$, and 63712, respectively). Concentrations of NEFA were measured with kit no. 994-75409 from Wako Chemicals (Neuss, Germany), and BHBA with kit no. RB1007 from Randox Laboratories Ltd. (Ibach, Switzerland). Plasma insulin, IGF-I, $\mathrm{T}_{3}$, and $\mathrm{T}_{4}$ were measured by RIA as described by Vicari et al. (2008). Milk $\mathrm{P}_{4}$ levels were measured by ELISA after an optimized sample preparation. Milk samples were thawed in a water bath and then skimming was performed by centrifugation at $3,300 \times g$ for $15 \min \left(4^{\circ} \mathrm{C}\right)$, as described by Kollmann et al. (2008). Concentrations of $\mathrm{P}_{4}$ were determined in skim milk by enzyme immunoassay as described by Meyer et al. (1986).

\section{Liver Tissue Collection, RNA Extraction, and Quantitative Real-Time Reverse Transcription-PCR}

In 19 of the 23 cows, the liver was sampled at 8 wk before expected parturition, within $1 \mathrm{~d}$ after parturition, and at 4 wk pp by blind percutaneous needle biopsy (Tru-Cut biopsy needle, Provet AG, Lyssach, Switzerland) under local anesthesia. Liver tissue (60-100 mg) was directly placed into an RNA stabilization reagent (RNAlater, Ambion, Applied Biosystems, Austin, TX) and stored at $-20^{\circ} \mathrm{C}$ until analyzed. Total RNA was isolated from liver samples using peqGOLD TriFast (PEQLAB Biotechnologie GmbH, Erlangen, Germany), according to the manufacturer's instructions, and quantified by spectrophotometry with a BioPhotometer (Vaudaux-Eppendorf, Basel, Switzerland). For reverse transcription, $1 \mu \mathrm{g}$ of extracted total RNA was reverse transcribed with $200 \mathrm{U}$ of Moloney Murine Leukemia Virus Reverse Transcriptase RNAase H Minus, Point Mutant (Promega Corp., Madison, WI) using 100 pmol of random hexamer primers (Invitrogen, Leek, the Netherlands). The obtained cDNA was diluted to a final concentration of $25 \mathrm{ng} / \mu \mathrm{L}$. Pyruvate carboxylase and cytosolic and mitochondrial PEPCK (PEPCKc and PEPCKm, respectively) were selected as target genes because they are involved in carbohydrate metabolism. Primers for PC, PEPCKc, and PEPCKm were according to Hammon et al. (2003), and primers of receptors for GH (GH-R), IGF-I (IGF-R1), and insulin (I-R) were as described by Pfaffl et al. (2002). The PCR quantification was performed with the RotorGene 6000 (Corbett Research, Sydney, Australia), using software version 1.7.40. Fluorescence take off was calculated with the "second derivative maximum" program option. A master mix of the following reaction components was prepared: $1.8 \mu \mathrm{L}$ of water, $1.0 \mu \mathrm{L}$ of forward primer $(5 \mathrm{pmol}), 1.0 \mu \mathrm{L}$ of reverse primer $(5$ 
pmol), $0.2 \mu \mathrm{L}$ of $50 \times$ SYBR Green $(20 \mathrm{pmol})$, and 5.0 $\mu \mathrm{L}$ of $2 \times$ SensiMix $\left(1 \mathrm{mM} \mathrm{MgCl}{ }_{2} ; 2 \times\right.$ SensiMix NoRef DNA Kit, Bioline USA Inc., Taunton, MA). Nine microliters of master mix and $1 \mu \mathrm{L}$ of sample volume, containing $20 \mathrm{ng}$ of cDNA, were used. The following 3 -step PCR program was used: denaturation for $10 \mathrm{~min}$ at $95^{\circ} \mathrm{C}, 40$ cycles of amplification (each consisting of 15 $\mathrm{s}$ at $95^{\circ} \mathrm{C}$, the primer-specific annealing temperature for $30 \mathrm{~s}$ (see Table 1), and extension at $72^{\circ} \mathrm{C}$ for $20 \mathrm{~s}$ and quantification of fluorescence), and finally a melting curve program $\left(60-95^{\circ} \mathrm{C}\right)$. The abundance of mRNA was calculated relative to the expression of the 2 reference genes, GAPDH and $\beta$-actin, which were observed to be stable across time points and between groups. The sequences of primers used for amplification of the 2 housekeeping genes were identical to Hammon et al. (2003).

\section{Identification of Luteal Activity After Parturition During the First Follicular Wave Postpartum}

When the $\mathrm{P}_{4}$ concentration in the skim milk increased to $>1 \mathrm{ng} / \mathrm{mL}$, the cow was confirmed as having luteal activity (Stevenson and Britt, 1979). This includes short and immature corpus luteum activity $(>1 \mathrm{ng} /$ $\mathrm{mL} ;<3 \mathrm{ng} / \mathrm{mL}$ ). Cows having luteal activity by $3 \mathrm{wk}$ pp were defined as ovulatory during the first follicular wave postpartum (ovulatory cows, OC), whereas those not having luteal activity by 3 wk pp were defined as anovulatory (anovulatory cows, AC).

\section{Statistical Analysis}

Before data analysis, EB data were averaged weekly. In addition, data on EB, BCS, metabolic hormones, metabolites, and enzymes were averaged for the prepartum and postpartum periods separately. StatView (StatView 5.0 software, Abacus Concepts Inc., Berkeley, CA) was used for data analysis, using the repeatedmeasures ANOVA procedure, including time (week, or prepartum vs. postpartum period), group ( $\mathrm{OC}$ or $\mathrm{AC})$, and their interaction in the model as fixed effects. Cow was used as repeated subject. When the interaction between occurrence of ovulation and time was significant $(P<0.05)$, pairwise comparisons of individual means were carried out using the Tukey-Kramer test. Results are reported as mean \pm standard error of the mean (SEM); differences with $P<0.05$ were considered significant.

\section{RESULTS}

Eleven of 23 experimental cows (48\%) showed resumption of ovarian activity within 3 wk pp (OC). The interval between calving and the resumption of ovarian activity was $19.3 \pm 0.7 \mathrm{~d}$ in $\mathrm{OC}$ and $43.3 \pm 7.8 \mathrm{~d}$ in $\mathrm{AC}$ $(P<0.05)$. Total milk yield until $15 \mathrm{wk}$ pp and daily milk production did not differ between $\mathrm{OC}$ and $\mathrm{AC}$ $(511 \pm 25 \mathrm{~kg}$ and $34.1 \pm 1.6 \mathrm{~kg}$ in $\mathrm{OC}$ vs. $493 \pm 35 \mathrm{~kg}$ and $32.9 \pm 2.4 \mathrm{~kg}$ in $\mathrm{AC}$, respectively). Energy balance during the dry period tended to be higher in $\mathrm{OC}$ than

Table 1. Abundance of mRNA (mean \pm SEM) of hepatic factors in ovulatory $(\mathrm{OC}, \mathrm{n}=8$ ) and anovulatory $(\mathrm{AC}, \mathrm{n}=11)$ cows at $8 \mathrm{wk}$ before expected parturition, within $1 \mathrm{~d}$ after parturition, and at 4 wk postpartum

\begin{tabular}{|c|c|c|c|c|}
\hline Parameter $^{1}$ & $\begin{array}{l}\text { Time relative } \\
\text { to parturition }\end{array}$ & $\begin{array}{c}\mathrm{OC} \\
(\mathrm{n}=8)\end{array}$ & $\begin{array}{c}\mathrm{AC} \\
(\mathrm{n}=11)\end{array}$ & $\begin{array}{l}\text { Significance of } \\
\text { differences }\end{array}$ \\
\hline \multirow[t]{3}{*}{ GH-R } & $-8 \mathrm{wk}$ & $9.3 \pm 0.5$ & $9.8 \pm 0.6$ & NS \\
\hline & $+1 \mathrm{~d}$ & $8.1 \pm 0.7$ & $9.2 \pm 0.6$ & NS \\
\hline & $+4 \mathrm{wk}$ & $8.9 \pm 0.3$ & $9.3 \pm 0.4$ & NS \\
\hline \multirow[t]{3}{*}{ I-R } & $-8 \mathrm{wk}$ & $10.9 \pm 1.1$ & $13.2 \pm 0.8^{\mathrm{x}}$ & NS \\
\hline & Partum & $11.9 \pm 0.8$ & $12.4 \pm 1.0^{\mathrm{xy}}$ & NS \\
\hline & $+4 \mathrm{wk}$ & $11.8 \pm 1.1$ & $11.5 \pm 0.9^{\mathrm{y}}$ & NS \\
\hline \multirow[t]{3}{*}{ IGF-R1 } & $-8 \mathrm{wk}$ & $6.5 \pm 0.4$ & $6.9 \pm 0.6$ & NS \\
\hline & Partum & $7.4 \pm 1.3$ & $7.1 \pm 0.7$ & NS \\
\hline & $+4 \mathrm{wk}$ & $6.0 \pm 0.5$ & $6.2 \pm 0.7$ & NS \\
\hline \multirow[t]{3}{*}{$\mathrm{PC}$} & $-8 \mathrm{wk}$ & $14.0 \pm 0.5$ & $13.8 \pm 0.4^{\mathrm{xy}}$ & NS \\
\hline & Partum & $14.1 \pm 0.5$ & $14.8 \pm 0.6^{\mathrm{x}}$ & NS \\
\hline & $+4 \mathrm{wk}$ & $13.9 \pm 0.3$ & $13.6 \pm 0.5^{y}$ & NS \\
\hline \multirow[t]{3}{*}{ PEPCKc } & $-8 \mathrm{wk}$ & $14.6 \pm 0.8$ & $14.5 \pm 0.6$ & NS \\
\hline & Partum & $13.8 \pm 0.7$ & $14.2 \pm 1.2$ & NS \\
\hline & $+4 \mathrm{wk}$ & $14.7 \pm 0.7$ & $15.0 \pm 0.4$ & NS \\
\hline \multirow[t]{3}{*}{ PEPCKm } & $-8 \mathrm{wk}$ & $8.6 \pm 0.4^{\mathrm{a}}$ & $9.4 \pm 0.5^{\mathrm{y}}$ & NS \\
\hline & Partum & $9.8 \pm 0.5^{\mathrm{b}}$ & $11.1 \pm 0.7^{\mathrm{x}}$ & NS \\
\hline & $+4 \mathrm{wk}$ & $9.5 \pm 0.2^{\mathrm{ab}}$ & $9.8 \pm 0.4^{y}$ & NS \\
\hline
\end{tabular}

$\overline{\mathrm{a}, \mathrm{b}, \mathrm{x}, \mathrm{y}}$ Means with different superscript letters within a column (a,b in OC; $\mathrm{x}, \mathrm{y}$ in $\mathrm{AC})$ differ $(P<0.05)$.

${ }^{1} \mathrm{GH}-\mathrm{R}=$ growth hormone receptor; I-R = insulin receptor; IGF-R1 = IGF-1 receptor; PC = pyruvate carboxylase; PEPCKc = phosphoenolpyruvate carboxykinase-cytosolic; PEPCKm = phosphoenolpyruvate carboxykinase-mitochondrial. 


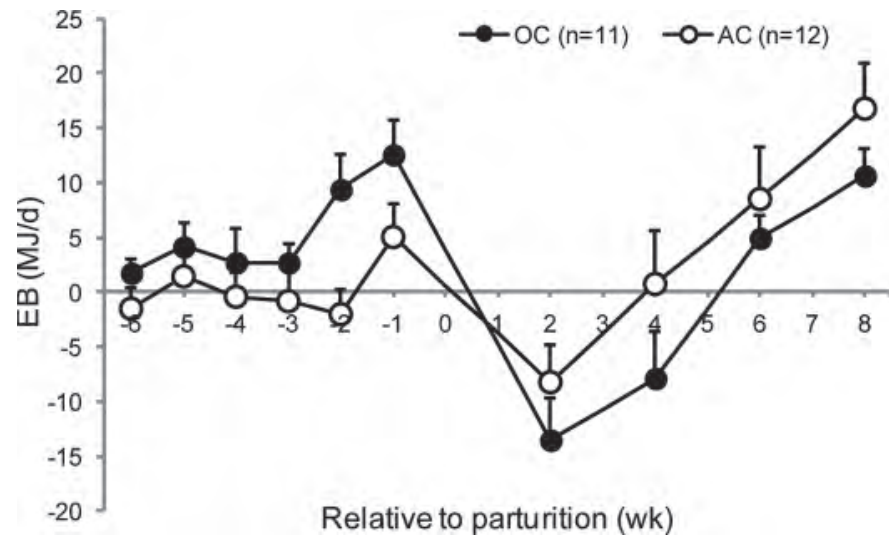

Figure 1. Energy balance (EB, MJ/d; mean \pm SEM) of ovulatory cows (OC, solid symbols) and anovulatory cows (AC, open symbols) during the experimental period; EB during the dry period tended to be higher $(P=0.07)$ in $\mathrm{OC}$ than in $\mathrm{AC}$; however, no differences were observed between the groups during the postpartum period.

in $\mathrm{AC}(5.26 \pm 1.18$ vs. $-0.01 \pm 1.06 \mathrm{MJ} / \mathrm{d}$, respectively; $P=0.07)$. In contrast, no differences of $\mathrm{EB}$ were observed between groups during the postpartum period (Figure 1). The most positive $\mathrm{EB}$ was observed in $\mathrm{OC}$ at $1 \mathrm{wk}$ before calving $(12.57 \pm 3.07 \mathrm{MJ} / \mathrm{d})$, and the greatest difference between $\mathrm{OC}$ and $\mathrm{AC}$ was recorded at $2 \mathrm{wk}$ before parturition $(9.40 \pm 3.18$ vs. $-2.01 \pm$ $2.19 \mathrm{MJ} / \mathrm{d}$, respectively).

Figure 2 shows the circulating plasma metabolites, metabolic hormones, enzymes, and BCS during the experimental period. Plasma glucose $(P<0.01)$ and IGF-1 $(P<0.05)$ concentrations were higher in OC than in AC during the dry period, and insulin concentration tended to be higher $(P=0.06)$ and AST activity tended to be lower $(P=0.09)$ in OC during the dry period, although the postpartum concentrations were similar between the 2 groups. In addition, for insulin concentration, significant treatment and time effects were observed $(P<0.05)$ in each period, but we found no effect of occurrence of ovulation. Moreover, plasma concentration of $\mathrm{T}_{3}$ was higher in $\mathrm{OC}$ than in $\mathrm{AC}(P<$ $0.05)$ in the dry period, and plasma concentration of $\mathrm{T}_{4}$ during dry period tended to be higher $(P=0.07)$ and its concentration during the postpartum period was higher $(P<0.05)$ in OC than in AC. Furthermore, a significant treatment and time effect was observed $(P$ $<0.05)$ for NEFA concentrations in each period, but we found no effect of occurrence of ovulation. Levels of T-cholesterol, BHBA, and GGT did not differ between $\mathrm{OC}$ and $\mathrm{AC}$ in each period. For BCS, OC showed higher values than $\mathrm{AC}$ during the postpartum period $(P<0.05)$.

Table 1 shows the mRNA abundance for GH-R, I-R, IGF-R1, PC, PEPCKc, and PEPCKm in OC $(n=8)$ and $\mathrm{AC}(\mathrm{n}=11)$ at $8 \mathrm{wk}$ before expected parturition, within $1 \mathrm{~d}$ after parturition, and at $4 \mathrm{wk}$ pp. None of the measured hepatic factors differed between OC and AC. However, hepatic I-R in AC decreased from dry off to early lactation $(P<0.05)$, and PC tended to increase from dry off to parturition $(P=0.07)$ and decreased again in early lactation $(P<0.05)$ only in $\mathrm{AC}$. Both I-R and PC remained unchanged in OC. The mRNA abundance of PEPCKm increased from dry off to parturition in both groups $(P<0.05)$ and remained high in OC, whereas PEPCKm decreased again in early lactation in $\mathrm{AC}(P<0.05)$.

\section{DISCUSSION}

The current study showed clearly that the major effect of energy status and metabolism on the resumption of ovarian activity occurs during the dry period. However, hepatic mRNA abundance encoding for gluconeogenic enzymes and metabolic hormone receptors did not reflect the plasma levels of metabolic parameters and was not related to ovarian activity at any time during the study.

During the dry period, plasma concentrations of glucose, insulin, IGF-1, $\mathrm{T}_{3}$, and $\mathrm{T}_{4}$ were higher, and EB tended to be higher in OC than in AC. Plasma glucose and insulin concentrations during the postpartum period and IGF-1 concentration during the dry and postpartum periods at the first follicular wave are higher in ovulatory cows than in anovulatory cows (Beam and Butler, 1998; Kawashima et al., 2007b). Taylor et al. (2004) showed that low circulating IGF-I concentration is closely related to the delayed first ovulation and infertility. In addition, Reist et al. (2003) showed that high plasma concentrations of $\mathrm{T}_{3}$ and $\mathrm{T}_{4}$ pp were associated with an early start of the ovarian cycle. Moreover, the higher EB during late pregnancy in ovulatory cows has also been observed by Butler et al. (2006). Several studies suggest an association between NEB and the onset of ovarian cyclicity in periparturient cows due to changes in LH pulse frequency (Beam and Butler, 1999; Butler, 2000). In the present study, EB differed only tangentially between $\mathrm{OC}$ and AC. However, BCS (which is closely related to EB) was higher in OC than $\mathrm{AC}$ during the postpartum period. A decrease of BCS was previously shown to occur after the reduction of DMI and EB (Gross et al., 2011; Gumen et al., 2011). Therefore, the higher BCS during the postpartum period in ovulatory cows likely reflected the better energy status and metabolism during the prepartum period in this group. In fact, the relationship between BCS and reproductive performance has been shown repeatedly (Beam and Butler, 1999; Roche et al., 2009). Our data 

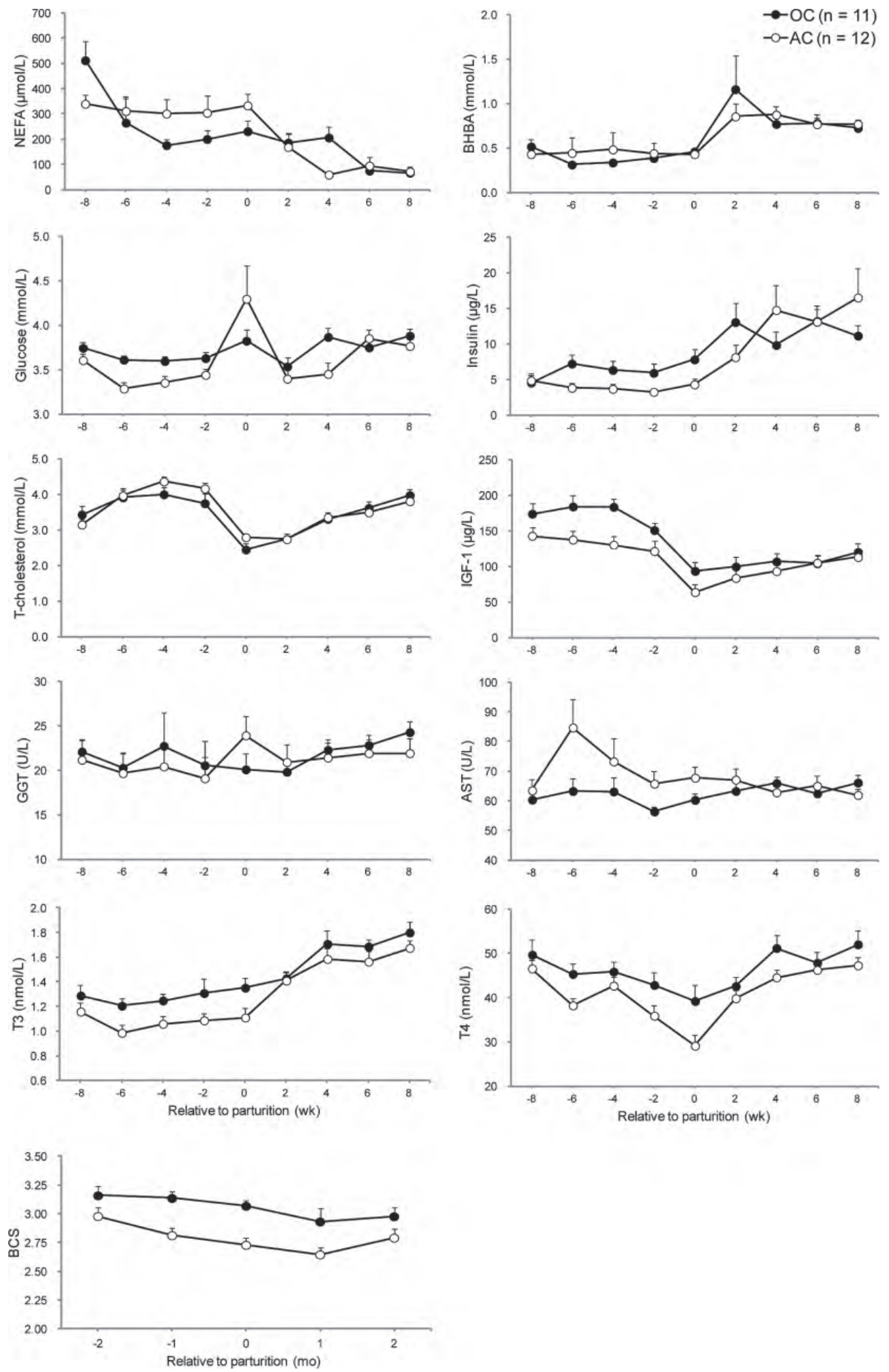

Figure 2. Plasma concentrations (mean \pm SEM) of metabolites and hormones, activities of enzymes, and BCS of ovulatory cows (OC, solid symbols) and anovulatory cows (AC, open symbols) during the experimental period. Plasma glucose $(P<0.01)$, IGF-1 $(P<0.05)$, and $3,5,3^{\prime}$-triiodothyronine $\left(\mathrm{T}_{3} ; P<0.05\right)$ concentrations were higher in $\mathrm{OC}$ than AC during the dry period, and insulin $(P=0.06)$ and thyroxine $\left(\mathrm{T}_{4} ; P=0.07\right)$ concentrations tended to be higher and aspartate aminotransferase (AST) level tended to be lower $(P=0.09)$ in OC during the dry period. Body condition score $(P<0.05)$ and plasma $\mathrm{T}_{4}$ concentration $(P<0.05)$ during the postpartum period was higher in $\mathrm{OC}$ than in $\mathrm{AC}$ cows. For other traits [NEFA, BHBA, gamma-glutamyl transferase (GGT), and total (T)-cholesterol], no significant differences were observed between $\mathrm{OC}$ and $\mathrm{AC}$ in each period. 
clearly indicate that the energy status during the dry period, as reflected by plasma glucose, insulin, IGF-1, $\mathrm{T}_{3}$, and $\mathrm{T}_{4}$ levels and $\mathrm{EB}$, is closely associated with BCS and the resumption of ovarian function postpartum.

In addition to this orchestrated effect on ovarian function during the dry period, ovulatory animals continued to show higher values of $\mathrm{T}_{4}$ during the postpartum period. A direct stimulatory effect of $\mathrm{T}_{4}$ on bovine theca and granulosa cells has been demonstrated previously (Spicer et al., 2001). Likely, the maintenance of higher $\mathrm{T}_{4}$ in ovulatory animals beyond parturition continued to stimulate ovarian follicular development and hence contributed to trigger the resumption of ovarian activity.

The differences in plasma concentrations of metabolic parameters observed for the variation in resumption of ovarian activity were not reflected by differences between $\mathrm{OC}$ and $\mathrm{AC}$ for hepatic mRNA abundance encoding for gluconeogenic enzymes and metabolic hormone receptors. However, changes over time were observed. Observations made in anovulatory cows may be confirmed by Karcher et al. (2007), who observed greater expression of $\mathrm{PC}$ on $\mathrm{d} 1$ postpartum compared with on $28 \mathrm{~d}$ or $14 \mathrm{~d}$ prepartum. The greater gene expression of $\mathrm{PC}$ in the liver might be the consequence of using relatively more lactate and amino acids as substrates for gluconeogenesis (Hammon et al., 2009). Therefore, in anovulatory cows with lower energy status from the prepartum period, the gluconeogenic substrate might shift to more lactate and amino acids at calving compared with other time points. A similar pattern was observed for PEPCKm mRNA, which increased from parturition to 4 wk pp in $\mathrm{AC}$ compared with $\mathrm{OC}$, thereby confirming the expected upregulation of PEPCK in response to feed restriction as observed in nonruminants, reflecting a combined adaptation with PC to the increased flux of lactate as a precursor for gluconeogenesis (Johnson and Otterby, 1981). Similar changes over time for PC and PEPCKm transcripts were not observed in ovulatory cows, which could suggest that energy demand at the onset of lactation was moderate, and ovulatory cows were able to cover demands in early lactation with sufficient intake and without marked changes for gluconeogenesis at the molecular level (Velez and Donkin, 2004).

Total GH-R and IGF-R1 mRNA expression did not decline at parturition as expected, characterizing the uncoupling of the GH axis that typically occurs in postpartum dairy cows (Lucy, 2001; Radcliff et al., 2003). Total GH-R and IGF-R1 mRNA were similar between the groups, despite a higher plasma IGF-1 concentration during the dry period in $\mathrm{OC}$ compared with $\mathrm{AC}$ in the present study. The higher plasma IGF-1 concentra- tions in the dry period in OC likely reflected the energy status in that period, because IGF-1 is clearly changed by feeding level (Armstrong et al., 2003).

Furthermore, in AC, the expression of I-R mRNA was higher at 10 wk before expected parturition than that in the postpartum period in this study. Our recent study showed that the mRNA abundance of insulin receptor in the liver was increased after parturition and feed restriction in dairy cows (Gross et al., 2011), and this view supports the present results that energy status, including hepatic gene expression and metabolic status in blood, during the prepartum period was lower in $\mathrm{AC}$ than in $\mathrm{OC}$.

\section{CONCLUSIONS}

Energy status, plasma concentrations of glucose, insulin, IGF-1, $\mathrm{T}_{3}$, and $\mathrm{T}_{4}$ during the dry period, and changes of hepatic gene expression of I-R, PC, and PEPCKm from dry off to early lactation seem to be the major factors that influence the occurrence of the first ovulation postpartum. Higher plasma $\mathrm{T}_{4}$ concentrations during the postpartum period induced by higher energy status during the dry period may directly promote ovulation of the first dominant follicle in high-producing dairy cows under good feeding management.

\section{ACKNOWLEDGMENTS}

This study was supported by the Global Center of Excellence (COE) program of the Ministry of Education, Culture, Sports, Science and Technology, and the Persistency of Lactation in Dairy Cattle Project of National Agriculture and Food Research Organization, Japan. We thank Claudine Morel and Yolande Zbinden (Vetsuisse Faculty, University of Bern, Bern, Switzerland) for their technical support and performance of laboratory analyses.

\section{REFERENCES}

ALP (Agroscope Liebefeld-Posieux). 2007. Fütterungsempfehlungen und Nährwerttabellen für Wiederkäuer (Feeding Recommendations and Nutrient Tables). Forschungsanstalt Agroscope Liebefeld-Posieux, Posieux, Switzerland.

Armstrong, D. G., J. G. Gong, and R. Webb. 2003. Interactions between nutrition and ovarian activity in cattle: Physiological, cellular and molecular mechanisms. Reprod. Suppl. 61:403-414.

Beam, S. W., and W. R. Butler. 1998. Energy balance, metabolic hormones, and early postpartum follicular development in dairy cows fed prilled lipid. J. Dairy Sci. 81:121-131.

Beam, S. W., and W. R. Butler. 1999. Effects of energy balance on follicular development and first ovulation in postpartum dairy cows. J. Reprod. Fertil. Suppl. 54:411-424.

Butler, S. T., A. L. Marr, S. H. Pelton, R. P. Radcliff, M. C. Lucy, and W. R. Butler. 2003. Insulin restores GH responsiveness during lactation-induced negative energy balance in dairy cattle: Ef- 
fects on expression of IGF-I and GH receptor 1A. J. Endocrinol. 176:205-217.

Butler, S. T., S. H. Pelton, and W. R. Butler. 2006. Energy balance, metabolic status, and the first postpartum ovarian follicle wave in cows administered propylene glycol. J. Dairy Sci. 89:2938-2951.

Butler, W. R. 2000. Nutritional interactions with reproductive performance in dairy cattle. Anim. Reprod. Sci. 60-61:449-457.

Butler, W. R., and R. D. Smith. 1989. Interrelationships between energy balance and postpartum reproductive function in dairy cattle. J. Dairy Sci. 72:767-783.

Cavestany, D., M. Kulcsar, D. Crespi, Y. Chilliard, A. La Manna, O. Balogh, M. Keresztes, C. Delavaud, G. Huszenicza, and A. Meikle. 2009a. Effect of prepartum energetic supplementation on productive and reproductive characteristics, and metabolic and hormonal profiles in dairy cows under grazing conditions. Reprod. Domest. Anim. 44:663-671.

Cavestany, D., C. Vinoles, M. A. Crowe, A. La Manna, and A. Mendoza. 2009b. Effect of prepartum diet on postpartum ovarian activity in Holstein cows in a pasture-based dairy system. Anim. Reprod. Sci. 114:1-13.

Darwash, A. O., G. E. Lamming, and J. A. Woolliams. 1997. The phenotypic association between the interval to post-partum ovulation and traditional measures of fertility in dairy cattle. Anim. Sci. $65: 9-16$.

de Feu, M. A., A. C. Evans, P. Lonergan, and S. T. Butler. 2009. The effect of dry period duration and dietary energy density on milk production, bioenergetic status, and postpartum ovarian function in Holstein-Friesian dairy cows. J. Dairy Sci. 92:6011-6022.

Ferguson, J. D., D. T. Galligan, and N. Thomsen. 1994. Principal descriptors of body condition score in Holstein cows. J. Dairy Sci. 77:2695-2703.

Glister, C., D. S. Tannetta, N. P. Groome, and P. G. Knight. 2001. Interactions between follicle-stimulating hormone and growth factors in modulating secretion of steroids and inhibin-related peptides by nonluteinized bovine granulosa cells. Biol. Reprod. 65:1020-1028.

Graf, C. M., M. Kreuzer, and F. Dohme. 2005. Effects of supplemental hay and corn silage versus full-time grazing on ruminal $\mathrm{pH}$ and chewing activity of dairy cows. J. Dairy Sci. 88:711-725.

Greenfield, R. B., M. J. Cecava, and S. S. Donkin. 2000. Changes in mRNA expression for gluconeogenic enzymes in liver of dairy cattle during the transition to lactation. J. Dairy Sci. 83:1228-1236.

Gross, J., H. A. van Dorland, R. M. Bruckmaier, and F. J. Schwarz. 2011. Performance and metabolic profile of dairy cows during a lactational and deliberately induced negative energy balance with subsequent realimentation. J. Dairy Sci. 94:1820-1830.

Gumen, A., A. Keskin, G. Yilmazbas-Mecitoglu, E. Karakaya, and M. Wiltbank. 2011. Dry period management and optimization of post-partum reproductive management in dairy cattle. Reprod. Domest. Anim. 46(Suppl. 3):11-17.

Gutiérrez, C. G., B. K. Campbell, and R. Webb. 1997. Development of a long-term bovine granulosa cell culture system: Induction and maintenance of estradiol production, response to follicle-stimulating hormone, and morphological characteristics. Biol. Reprod. $56: 608-616$.

Hammon, H. M., S. N. Sauter, M. Reist, Y. Zbinden, C. Philipona, C. Morel, and J. W. Blum. 2003. Dexamethasone and colostrum feeding affect hepatic gluconeogenic enzymes differently in neonatal calves. J. Anim. Sci. 81:3095-3106.

Hammon, H. M., G. Stürmer, F. Schneider, A. Tuchscherer, H. Blum, T. Engelhard, A. Genzel, R. Staufenbiel, and W. Kanitz. 2009. Performance and metabolic and endocrine changes with emphasis on glucose metabolism in high-yielding dairy cows with high and low fat content in liver after calving. J. Dairy Sci. 92:1554-1566.

Johnson, D. G., and D. E. Otterby. 1981. Influence of dry period diet on early postpartum health, feed intake, milk production, and reproductive efficiency of Holstein cows. J. Dairy Sci. 64:290-295.

Karcher, E. L., M. M. Pickett, G. A. Varga, and S. S. Donkin. 2007. Effect of dietary carbohydrate and monensin on expression of gluconeogenic enzymes in liver of transition dairy cows. J. Anim. Sci. 85:690-699.
Kawashima, C., C. Amaya Montoya, Y. Masuda, E. Kaneko, M. Matsui, T. Shimizu, N. Matsunaga, K. Kida, Y.-I. Miyake, M. Suzuki, and A. Miyamoto. 2007a. A positive relationship between the first ovulation postpartum and the increasing rate of milk yield in the first part of lactation in high-producing dairy cows. J. Dairy Sci. 90:2279-2282.

Kawashima, C., S. Fukihara, M. Maeda, E. Kaneko, C. Amaya Montoya, M. Matsui, T. Shimizu, N. Matsunaga, K. Kida, Y.-I. Miyake, D. Schams, and A. Miyamoto. 2007b. Relationship between metabolic hormones and ovulation of dominant follicle during the first follicular wave postpartum in high-producing dairy cows. Reproduction 133:155-163.

Kollmann, M. T., M. Locher, F. Hirche, K. Eder, H. H. Meyer, and R. M. Bruckmaier. 2008. Effects of tryptophan supplementation on plasma tryptophan and related hormone levels in heifers and dairy cows. Domest. Anim. Endocrinol. 34:14-24.

Lucy, M. C. 2001. Reproductive loss in high-producing dairy cattle: Where will it end? J. Dairy Sci. 84:1277-1293.

Lucy, M. C. 2003. Mechanisms linking nutrition and reproduction in postpartum cows. Reprod. Suppl. 61:415-427.

Lucy, M. C., C. R. Staples, W. W. Thatcher, P. S. Erickson, R. M. Cleale, J. L. Firkins, J. H. Clark, M. R. Murphy, and B. O. Brodie. 1992. Influence of diet composition, dry matter intake, milk production and fertility in dairy cows. Anim. Prod. 54:323-331.

Meyer, H. H. D., B. Güven, and H. Karg. 1986. Enzymimmuntests (EIA) auf mikrotitrationsplatten zur progesteronbestimmung in magermilchproben. Wien Tieräztl. Monatsschr. 73:86-94.

Pfaffl, M. W., A. Daxenberger, M. Hageleit, and H. H. Meyer. 2002. Effects of synthetic progestagens on the mRNA expression of androgen receptor, progesterone receptor, oestrogen receptor alpha and beta, insulin-like growth factor-1 (IGF-1) and IGF-1 receptor in heifer tissues. J. Vet. Med. A Physiol. Pathol. Clin. Med. 49:57-64

Radcliff, R. P., B. L. McCormack, B. A. Crooker, and M. C. Lucy. 2003. Plasma hormones and expression of growth hormone receptor and insulin-like growth factor-I mRNA in hepatic tissue of periparturient dairy cows. J. Dairy Sci. 86:3920-3926.

Reist, M., D. K. Erdin, D. von Euw, K. M. Tschumperlin, H. Leuenberger, H. M. Hammon, C. Morel, C. Philipona, Y. Zbinden, N. Kunzi, and J. W. Blum. 2003. Postpartum reproductive function: Association with energy, metabolic and endocrine status in high yielding dairy cows. Theriogenology 59:1707-1723.

Roche, J. F., D. Mackey, and M. D. Diskin. 2000. Reproductive management of postpartum cows. Anim. Reprod. Sci. 60-61:703-712.

Roche, J. R., N. C. Friggens, J. K. Kay, M. W. Fisher, K. J. Stafford, and D. P. Berry. 2009. Invited review: Body condition score and its association with dairy cow productivity, health, and welfare. J. Dairy Sci. 92:5769-5801.

Sakaguchi, M., Y. Sasamoto, T. Suzuki, Y. Takahashi, and Y. Yamada. 2004. Postpartum ovarian follicular dynamics and estrous activity in lactating dairy cows. J. Dairy Sci. 87:2114-2121.

Savio, J. D., M. P. Boland, N. Hynes, and J. F. Roche. 1990. Resumption of follicular activity in the early post-partum period of dairy cows. J. Reprod. Fertil. 88:569-579.

Senatore, E. M., W. R. Butler, and P. A. Oltenacu. 1996. Relationship between energy balance and postpartum ovarian activity and fertility in first lactation dairy cows. Anim. Sci. 62:17-23.

Spicer, L. J., J. Alonso, and C. S. Chamberlain. 2001. Effects of thyroid hormones on bovine granulosa and thecal cell function in vitro: Dependence on insulin and gonadotropins. J. Dairy Sci. 84:1069-1076.

Spicer, L. J., E. Alpizar, and S. E. Echternkamp. 1993. Effects of insulin, insulin-like growth factor I, and gonadotropins on bovine granulosa cell proliferation, progesterone production, estradiol production, and(or) insulin-like growth factor I production in vitro. J. Anim. Sci. 71:1232-1241.

Spicer, L. J., and R. E. Stewart. 1996. Interactions among basic fibroblast growth factor, epidermal growth factor, insulin, and insulinlike growth factor-I (IGF-I) on cell numbers and steroidogenesis of 
bovine thecal cells: role of IGF-I receptors. Biol. Reprod. 54:255263.

Staples, C. R., W. W. Thatcher, and J. H. Clark. 1990. Relationship between ovarian activity and energy status during the early postpartum period of high producing dairy cows. J. Dairy Sci. 73:938-947.

Stevenson, J. S., and J. H. Britt. 1979. Relationships among luteinizing hormone, estradiol, progesterone, glucocorticoids, milk yield, body weight and postpartum ovarian activity in Holstein cows. J. Anim. Sci. 48:570-577.

Taylor, V. J., Z. Cheng, P. G. Pushpakumara, D. E. Beever, and D. C. Wathes. 2004. Relationships between the plasma concentrations of insulin-like growth factor-I in dairy cows and their fertility and milk yield. Vet. Rec. 155:583-588.

Velez, J. C., and S. S. Donkin. 2004. Bovine somatotropin increases hepatic phosphoenolpyruvate carboxykinase mRNA in lactating dairy cows. J. Dairy Sci. 87:1325-1335.

Vicari, T., J. J. G. C. van den Borne, W. J. J. Gerrits, Y. Zbinden, and J. W. Blum. 2008. Postprandial blood hormone and metabolite concentrations influenced by feeding frequency and feeding level in veal calves. Domest. Anim. Endocrinol. 34:74-88. 